\title{
A new species and a new combination in Phaeostemma (Apocynaceae, Asclepiadoideae, Gonolobinae)
}

\author{
Gilberto Morillo', Alexander Krings ${ }^{2}$ \\ I Departamento de Botánica, Facultad de Ciencias Forestales y Ambientales, Universidad de Los Andes, Mérida \\ 5101-A, Venezuela 2 Herbarium, Department of Plant and Microbial Biology, North Carolina State University, \\ Raleigh, NC 27695-7612, U.S.A.
}

Corresponding author: Gilberto Morillo (gilberto12-10@hotmail.com)

Academic editor: L. Struwe | Received 17 October 2013 | Accepted 17 December 2013 | Published 16 January 2014

Citation: Morillo G, Krings A (2014) A new species and a new combination in Phaeostemma (Apocynaceae, Asclepiadoideae, Gonolobinae). PhytoKeys 33: 41-50. doi: 10.3897/phytokeys.33.6453

\begin{abstract}
Phaeostemma surinamensis Morillo \& Krings, sp. nov., a new species of Apocynaceae (Asclepiadoideae, Gonolobinae) is described and illustrated, and the new combination Phaeostemma fucata (Woodson) Morillo \& Krings, comb. nov., is made. The new species, known only from a lowland wet forest of Suriname, seems to be closely related to $P$. fucata, which is an endemic to Ptari-tepui, a sandstone mountain in the southeastern edge of the Venezuelan Guayana.
\end{abstract}

\section{Keywords}

Climbing milkweeds, Matelea, Suriname, Venezuela

\section{Introduction}

Phaeostemma E. Fourn. (Apocynaceae, Asclepiadoideae, Gonolobinae) is a South American genus of twining vines, distributed from southeastern Venezuela to Argentina. Heretofore, five names have been published in the genus- $P$. brandonianum Silveira, P. glaziovii E. Fourn., P. grandifolia Rusby, P. riedelii E. Fourn. and P. tigrina Woodson-however, based on morphology, neither P. grandifolia [syn. Matelea 
dasytricha (Schltr.) Woodson] nor P. tigrina appear to belong to Phaeostemma. The latter species appear to belong to the Andean lineage Lachnostoma Kunth (Morillo 2012). Members of Phaeostemma s.l. are recognized by stems, leaves and inflorescences densely pubescent, with brown to yellowish-red medium to long $(0.9-3 \mathrm{~mm})$ eglandular trichomes, mixed with some shorter $(0.5-1 \mathrm{~mm})$ eglandular, multiseptate trichomes, and in some species short $(0.15-0.4 \mathrm{~mm})$ glandular trichomes, leaves membranous to coriaceous, often broadly ovate, ovate-elliptic, elliptic or widely oblong, medium to large in size $(8-19.5 \times 3.8-12 \mathrm{~cm})$, bases shortly cordate, flowers large and broadly campanulate (corolla $23-37 \mathrm{~mm}$ in diameter; Fig. 1), corollas green to greenish-yellow, lobes ovate to deltate, sometimes reticulate, spreading, not ocellate, gynostegium stipitate, nectar chambers present, anthers subtriangular almost horizontal, radially prominent, pollinia narrowly or triangular pearshaped, and staminal corona fleshy, of 5 digitate lobes, partly adnate to the stipe and to the corolla tube. Phaeostemma is somewhat similar to Lachnostoma, but in Lachnostoma, the pubescence is usually shorter, with short to long $(0.12-1.60 \mathrm{~mm})$ eglandular trichomes, and rarely short $(0.10-0.25 \mathrm{~mm})$ glandular trichomes, and corollas usually smaller (12-20 mm in diameter; 26-34 $\mathrm{mm}$ in Lachnostoma uribei (Morillo) Morillo, inedit.), with lobes in natural position ovate-oblong to narrowly ovate-elliptic, longer than wide, partly due to recurved margins, in few species as long as wide, and bases narrowly campanulate or subtubular (Fig. 2). Species of Lachnostoma are known only from wet mountain forests (usually above $1400 \mathrm{~m}$ ) from the Andes of Peru, Ecuador and Colombia to the Costal Range of northern Venezuela, whereas species of Phaeostemma are known mainly from Tropical Rain Forests or in Austral Forests with araucarias (mostly below $1000 \mathrm{~m}$ ), from southeastern Guayana to northern Argentina.

Lachnostoma and Phaeostemma have been treated as nomenclatural synomyms of Matelea Aubl. sensu lato (Spellman and Morillo 1976; Morillo 1984; Fontella-Pereira et al. 1985), however, recent morphological studies (Morillo 2012), indicate that these genera differ from Matelea by the combination of dense, ubiquitous, long brown or yellowish-red pubescence in stems, leaves and inflorescences, corollas medium to large (12-37 $\mathrm{mm}$ in diameter), narrowly to broadly tubular, campanulate to subcampanulate, staminal corona segments (Cs) well-developed, connate to the base of the anthers, apically bifid or digitate, nectar chambers conspicuous, anthers radially prominent, with a concave outer face, retinacula broadly sagittate, and follicles (mature follicles unknown for Phaeostemma) ovate-oblong, with 5 wings and several conical projections. Members of Matelea s.s., in contrast, are recognized by stems glabrous to variously pubescent, pubescence in one or two lines, rarely ubiquitous, eglandular trichomes white or translucent, glandular capitate trichomes white, translucent, or with blackish capitula, corollas small to medium-size (less than $15 \mathrm{~mm}$ in diameter), usually rotate to subcampanulate, staminal corona segments (Cs) not distinct, usually appearing as ridges emanating from the central stipe, nectar chambers absent, retinacula narrowly sagittate or ovate-sagittate, and follicles narrowly ovate or fusiform, unwinged, costate, or 5-winged, conical projects absent. 
On-going work for various regional projects, including the Flora of the Guianas and the Biological Diversity of the Guiana Shield, has resulted in the discovery of a new species of Phaeostemma: P. surinamensis Morillo \& Krings [initially misidentified as Matelea glaziovii (E. Fourn.) Morillo = Phaeostemma glaziovii E. Fourn (Morillo 1997)]. A more careful study of the known species of the genus resulted in the present recognition of its distinctness. The new species is morphologically similar to $P$. fucata (Woodson) Morillo \& Krings, an endemic to Ptari-tepui, a sandstone mountain in the Venezuelan Guayana. The new species is described and distinguished below, and the requisite new combination made.

\section{Taxonomic treatment}

\section{Key to Phaeostemma}

1a Adaxial corolla lobe surface glabrous ............................................... 2

1b Adaxial corolla lobe surface pubescent ........................................4

2a Trichomes of stems, midveins, and inflorescences eglandular; corolla lobes longer than wide, adaxially obscurely reticulate when dry, leaf blades membranous; southeastern Brazil. P. riedelii

$2 \mathrm{~b}$ Trichomes of stems, midveins, and inflorescences both eglandular and glandular; corolla lobes as long as wide or wider than long, adaxially conspicuously reticulate when dry, leaf blades membranous or coriaceous; Guayana and Suriname.

3a Leaf blades coriaceous, broadly ovate to ovate-elliptic, marginally revolute, calyx lobes $8.5 \mathrm{~mm}$ long; Guayana (Venezuela).

3 b Leaf blades membranous, narrowly elliptic to oblanceolate-elliptic, marginally spreading; calyx lobes 5.5-6 mm long; Suriname.

P. surinamensis

4a Leaves subcoriaceous, veins on adaxial surface distinctly impressed, blades mostly broadly elliptic to ovate

P. brandonianum

$4 \mathrm{~b}$ Leaves membranous, veins on adaxial surface not or only slightly impressed, blades mostly narrowly elliptic to slightly obovate.

P. glaziovii

\section{Phaeostemma fucata (Woodson) Morillo \& Krings, comb. nov.}

urn:Isid:ipni.org:names:77135536-1

http://species-id.net/wiki/Phaeostemma_fucata

Figure 1

Matelea fucata Woodson, Fieldiana, Bot. ser. 28(3): 510. 1953.

Type. VENEZUELA. Bolivar, Ptari-tepui, densely forested slopes overlying sandstone, alt. 1800 m, 8 Nov 1944, J. Steyermark 59963 (Holotype: MO!; Isotypes: F!, NY!, VEN!). 


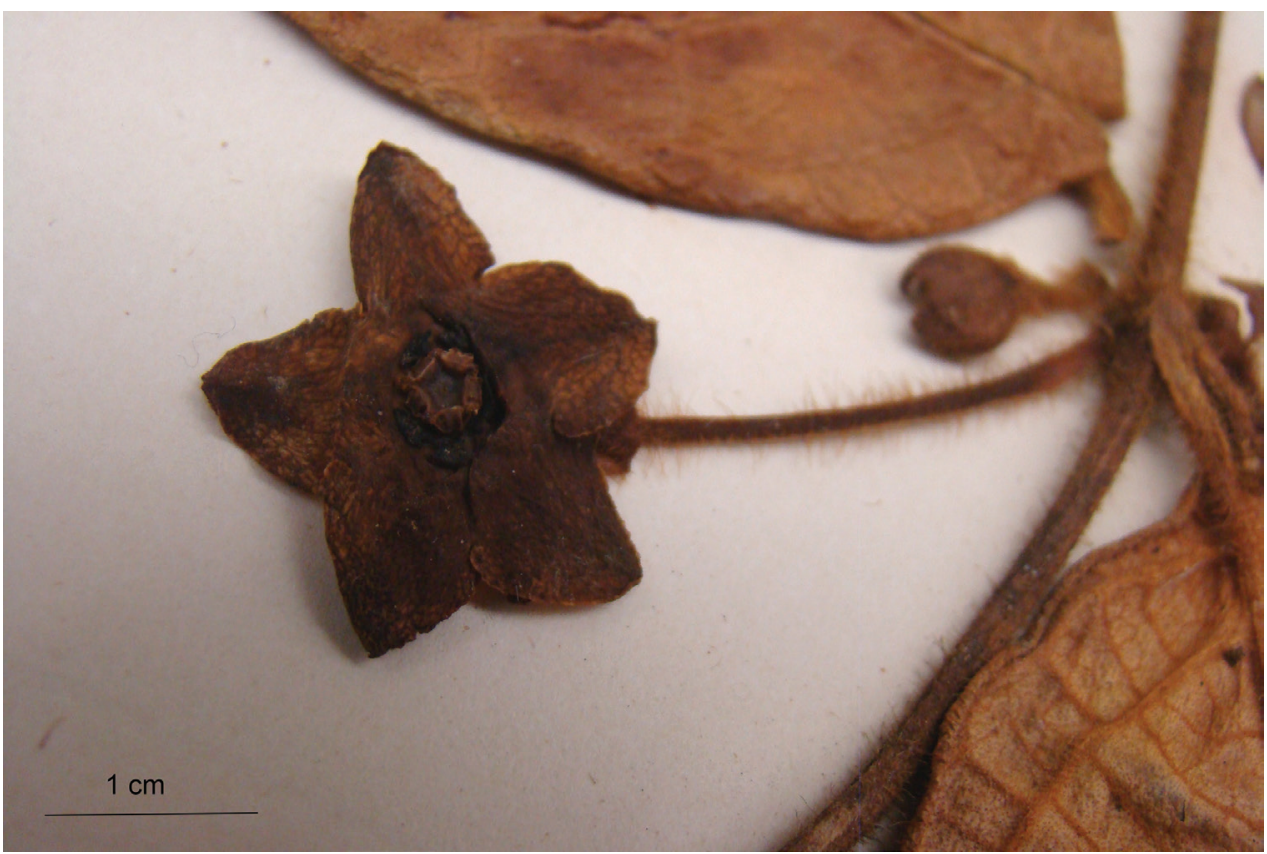

Figure I. Flower of Phaeostemma fucata (from Steyermark 59963, MO).

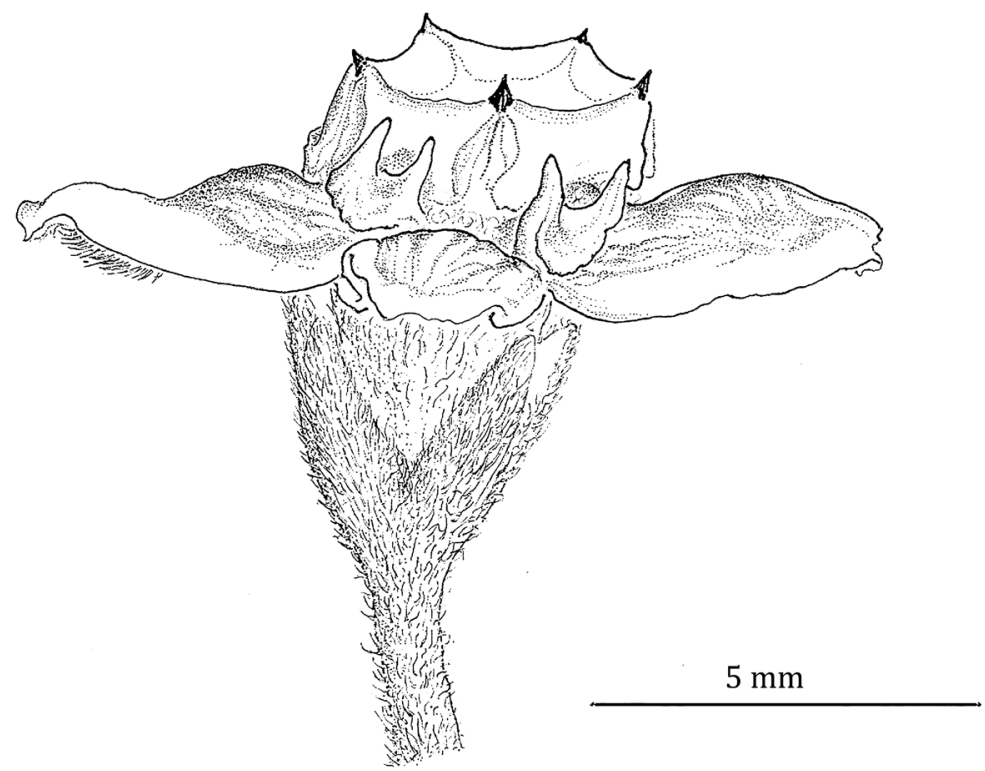

Figure 2. Flower of Lachnostoma ecuadorensis Morillo (Homeier et al. 1174, QCNE). 


\section{Phaeostemma surinamensis Morillo \& Krings, sp. nov.}

urn:Isid:ipni.org:names:77135538-1

http://species-id.net/wiki/Phaeostemma_surinamensis

Figures 3-6

A new species of Phaeostemma E. Fourn., morphologically similar to $P$. fucata (Woodson) Morillo \& Krings, but differing from the latter among other characters, by leaf blades thinner, membranous, narrowly elliptic to oblanceolate-elliptic, marginally spreading (vs. coriaceous, broadly ovate to ovate-elliptic, marginally revolute in $P$. $f u$ cata), calyx lobes $5.5-6 \mathrm{~mm}$ long (vs. $8.5 \mathrm{~mm}$ long in $P$. fucata), staminal corona lobes (Cs) 3-3.2 mm wide, narrower at lateral extremes (vs. $2.3 \mathrm{~mm}$ wide at apex, somewhat obtuse at lateral extremes [projections] in P. fucata), and pollinia longer, $1-1.15 \mathrm{~mm}$ (vs. ca. $0.8 \mathrm{~mm}$ long in P. fucata).

Type. SURINAME. Lely Mts., SW plateaus covered by ferrobauxite, in secondary vegetation, at end of airstrip, alt. 550-710 m, 1 Oct 1975, J.C. Lindeman, A.L. Stoffers, A.R.A. Górts-van Rijn \& M.J. Jansen-Jacobs 654 (Holotype: U!; Isotype: MO!).

Description. Vine, woody, slender. Stems densely pubescent, pubescence mixed eglandular and glandular trichomes, eglandular trichomes ubiquitous reddish-brown, stiff, usually spreading, multiseptate, $1.2-2.3 \mathrm{~mm}$ long, glandular trichomes spreading, scarce in mature stems, $0.2-0.3 \mathrm{~mm}$ long. Leaf blades membranous, narrowly elliptic to oblanceolate-elliptic, $10.2-15.0 \times 3.8-5.8 \mathrm{~cm}(1.6-1.8 \mathrm{~cm}$ wide at base), apex short acute, base narrowly and shortly cordate, trichomes of surfaces, veins, and margins mixed, yellowish-red, adaxial surface strigose, eglandular multicelled trichomes antrorse, curved to subappressed $0.7-1.3 \mathrm{~mm}$ long, glandular trichomes 3-4-celled, spreading, $0.15-0.2 \mathrm{~mm}$ long, present mainly on midvein, abaxial surface hispid or hispidulous, eglandular multicelled trichomes erect, $0.25-0.7 \mathrm{~mm}$ long, glandular trichomes spreading on the midvein, $0.1-0.2 \mathrm{~mm}$ long, midvein adaxially sulcate, abaxially prominent, lateral veins in 6-7 pairs, slightly to strongly prominent; colleters 2, digitate-cylindric, $2.8-3.3 \mathrm{~mm}$ long; petioles $1.1-1.7 \mathrm{~cm}$ long, densely pubescent, pubescence ubiquitous, eglandular multicelled trichomes spreading, $2.8-3.3 \mathrm{~mm}$ long, glandular trichomes 3-4-celled, spreading, $0.1-0.2$ $\mathrm{mm}$ long. Inflorescence racemiform, 2-4-flowered, 1(-2) flowers open at a time; peduncles 3-5 mm long, sparsely to moderately pubescent, pubescence ubiquitous, eglandular trichomes spreading, 1.2-2 mm long, glandular trichomes 3-4-celled, scarce, spreading, $0.2-0.3 \mathrm{~mm}$ long, rachis with scars ${ }_{2} 3-4 \mathrm{~mm}$ long, bracts oblong, $1.8-2 \mathrm{~mm}$ long, abaxially pubescent, eglandular trichomes multicelled, $0.3-0.4 \mathrm{~mm}$ long, pedicels $24-33 \mathrm{~mm}$ long, densely pubescent, pubescence ubiquitous, eglandular trichomes spreading, $0.9-2.5 \mathrm{~mm}$ long, glandular trichomes 3-4-celled, spreading, $0.15-0.3 \mathrm{~mm}$ long. Calyx $8.5 \mathrm{~mm}$ long, lobes green, dark red at apex, oblongelliptic, 5.5-6 × 2.4-2.6 mm, apex obtuse, margins entire, adaxial surface mostly glabrous, except few trichomes at apex, abaxial surface densely pubescent, eglandular multicelled trichomes spreading or antrorse, $0.9-1.5 \mathrm{~mm}$ long, glandular trichomes 


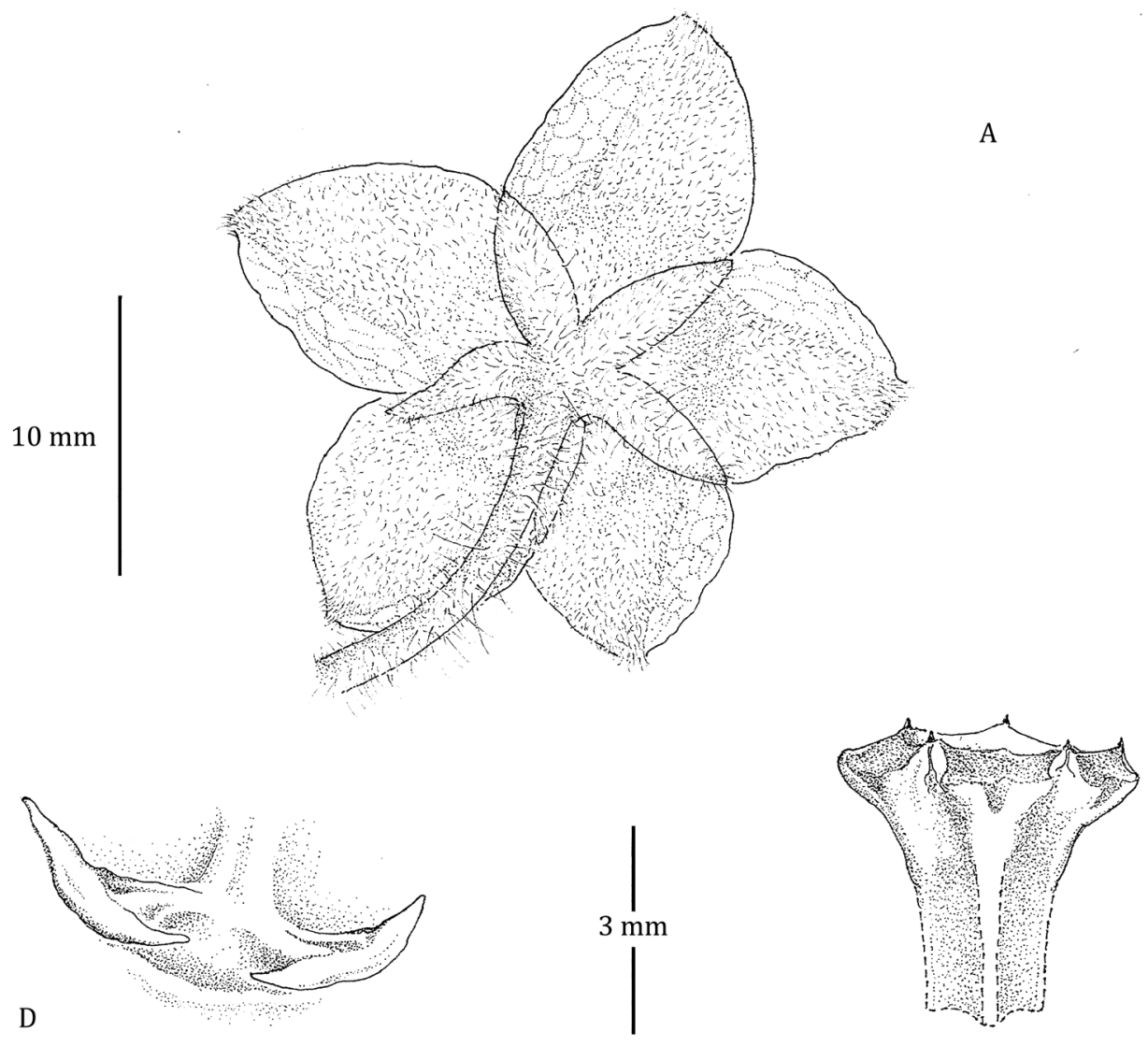

C

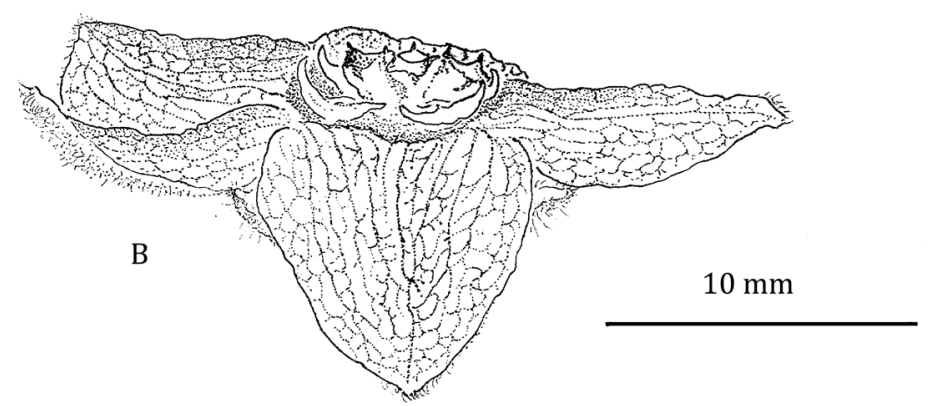

Figure 3. Flower of Phaeostemma surinamensis. A Abaxial view showing calyx and abaxial corolla lobes B Side view showing adaxial corolla surface and gynostegial corona C Style-head D Staminal corona (Cs). Based on Lindeman et al. 654 (U).

2-3-celled, spreading, $0.1-0.3 \mathrm{~mm}$ long, colleters 1 per sinus. Corolla pale green, with green vein network (fide collectoris), broadly subcampanulate, tube $5.5-5.8 \mathrm{~mm}$ long, up to $7 \mathrm{~mm}$ wide, sparsely short pubescent on the abaxial side, lobes imbricate 


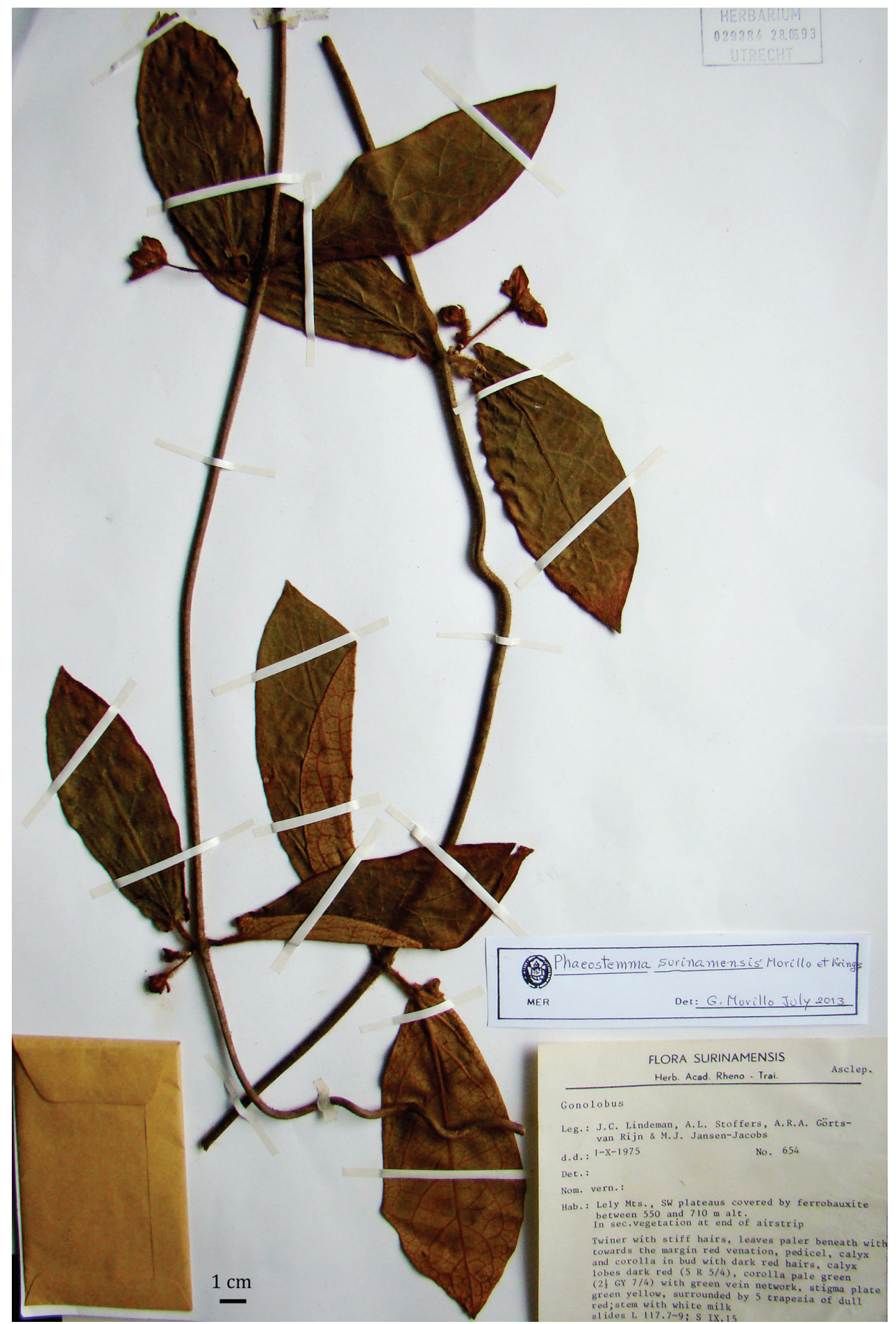

Figure 4. Holotype of Phaeostemma surinamensis (Lindeman et al. 654, U). 


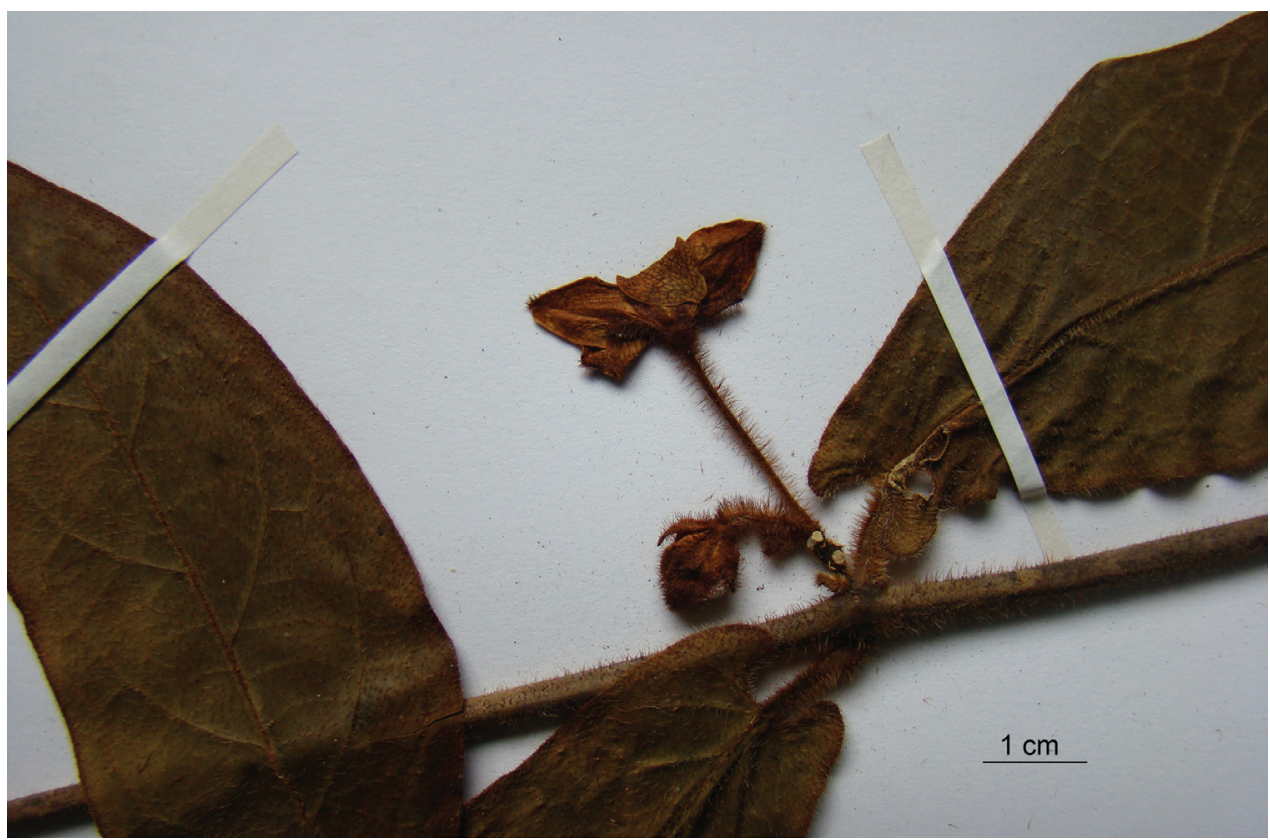

Figure 5. Detail of flower (side view) of Phaeostemma surinamensis from holotype (Lindeman et al. 654, U).

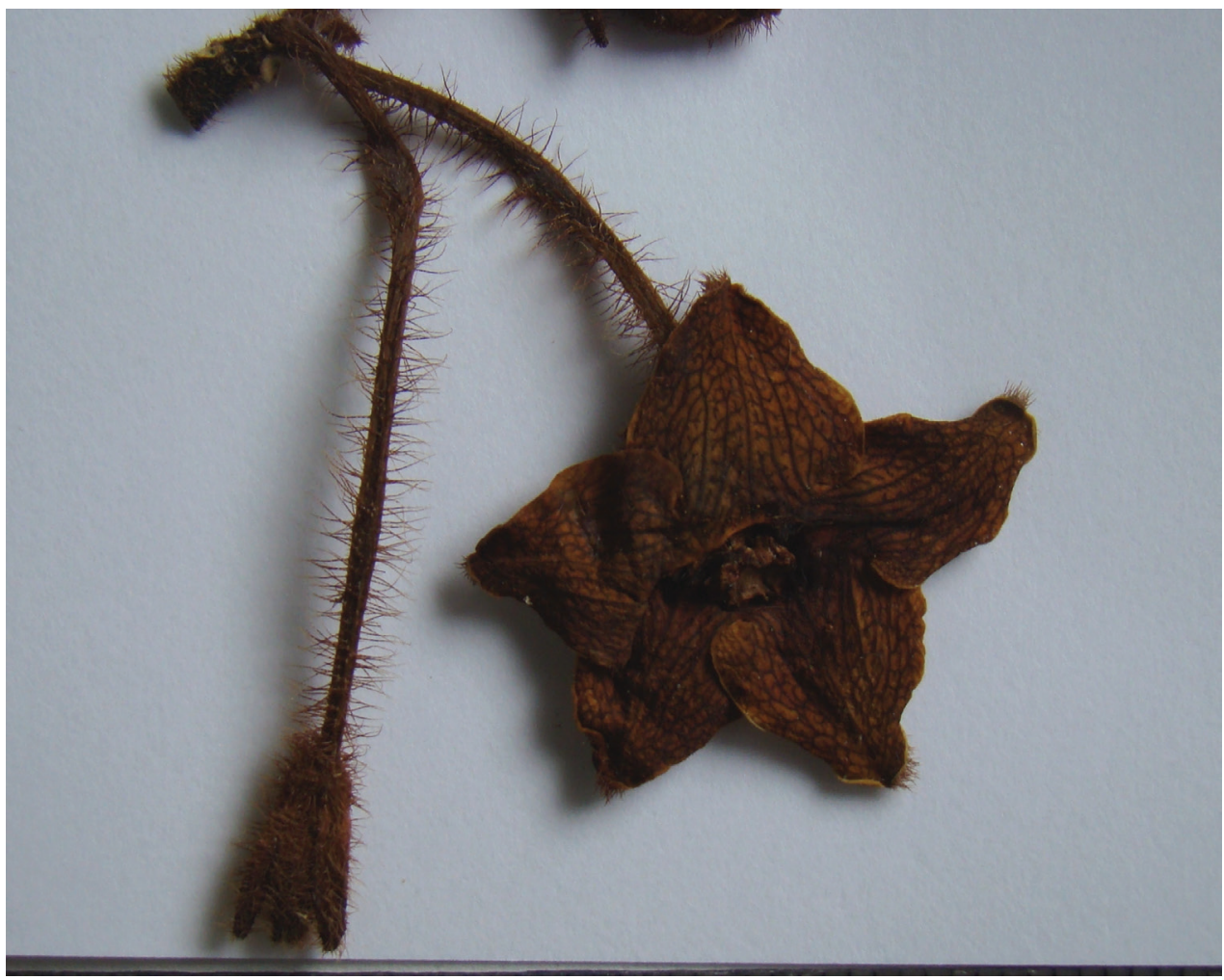

Figure 6. Detail of flower (adaxial view) of Phaeostemma surinamensis from holotype (Lindeman et al. 654, U). 
in bud, deltoid, spreading, 8-9 × 9-10 mm, adaxial surface glabrous, abaxial surface densely pubescent, eglandular trichomes reddish-brown curved, antrorse, 0.5$1.5 \mathrm{~mm}$ long, glandular trichomes 3-4-celled, scarce, $0.15-0.25 \mathrm{~mm}$ long, apices obtuse-emarginate, margins entire. Gynostegium stipitate, style-head green yellow, somewhat concave, $4.3-4.5 \mathrm{~mm}$ in diameter, stipe $2.5 \mathrm{~mm}$ long, terminal stylehead appendage absent. Corona gynostegial, fleshy, of 5 staminal (Cs) apically bifid segments fused to the corolla tube for most of its length, free in the upper 1.5-1.6 $\mathrm{mm}$, apical area bifurcate, dorsally flattened, $3-3.2 \mathrm{~mm}$ wide at apex; anthers subtriangular, $1.9-2.1 \mathrm{~mm}$ wide between wings; nectar chambers ca. $2.5 \times 2.6 \mathrm{~mm}$. Pollinarium: corpuscula narrowly obovate-sagittate, ca. $0.5 \times 0.33 \mathrm{~mm}$ long, caudicles ca. $0.22 \mathrm{~mm}$ long, pollinia triangular-pyriform, $1.0-1.15 \times 0.6 \mathrm{~mm}$. Follicles in very immature state, ca. $2 \mathrm{~cm}$ long, apparently 5-costate, densely glandular-pubescent, eglandular trichomes not seen, glandular trichomes 2-3-celled, $0.1-0.15 \mathrm{~mm}$ long. Seeds unknown.

Distribution and ecology. Growing on a plateau covered with ferrobauxite rock. Endemic to Suriname, in tropical rain forests 500 to $710 \mathrm{~m}$.

Phenology. Collected in flower in October.

Conservation status. Currently, very little is known regarding the status of this species.

\section{Excluded names}

Phaeostemma grandifolia Rusby, Descr. S. Am. Pl. 101. 1920. = Matelea dasytricha (Schltr.) Fontella, Bradea 4 (9): 55.1984 (syn. Gonolobus dasytrichus Schltr., Notizbl. Königl. Bot. Gart. Berlin 6(55): 177. 1914.)

Phaeostemma tigrina Woodson, Ann. Missouri Bot. Gard. 18: 560. 1931. = Lachnostoma tigrinum Kunth, Nov. Gen. Sp. (quarto ed.) 3: 199, t. 232. 1818[1819] (syn. Matelea humboldtiana Spellman \& Morillo, Phytologia 34(2): 152. 1976.)

\section{Acknowledgments}

We thank the following herbaria for allowing the study of specimens pertinent to this study: MO, NY, U, US, VEN. We also thank the kind staff of MO and US for their hospitality during our recent visits.

\section{References}

Fontella Pereira J, Hatschbach G, Hartmann RW (1985) Contribuçáo aos estudos das Asclepiadaceae do Paraná, 3. Boletim do Museu Botanico Municipal, Curitiba 64: 1-47.

Morillo G (1984) Nuevas especies, nuevos nombres y nuevas combinaciones en Matelea Aubl. Ernstia 24: 35-40. 
Morillo G (1997) Asclepiadaceae. In: Boggan J, Funk V, Kelloff C, Hoff M, Cremers G, Feuillet C (Eds) Checklist of the Plants of the Guianas, $2^{\text {nd }} \mathrm{ed}, 57-58$.

Morillo G (2012) Aportes al conocimiento de las Gonolobinae II. Pittieria 37: 141-180.

Spellman DL, Morillo G (1976) New names and new combinations in Asclepiadaceae. Phytologia 34(2): 152. 